\title{
Effects of Opuntia ficus-indica lectin on feeding, survival, and gut enzymes of maize weevil, Sitophilus zeamais
}

\author{
Carolina de Santana Souza ${ }^{1}$ Thamara Figueiredo Procópio ${ }^{1}$. \\ Bernardo do Rego Belmonte ${ }^{1}$ Patrícia Maria Guedes Paiva ${ }^{1}$. \\ Lidiane Pereira de Albuquerque ${ }^{2} \cdot$ Emmanuel Viana Pontual $^{3}$. \\ Thiago Henrique Napoleão ${ }^{1}$ (i)
}

Received: 23 January 2018/Accepted: 19 March 2018/Published online: 27 March 2018

(C) The Korean Society for Applied Biological Chemistry 2018

\begin{abstract}
In this study, the effects of Opuntia ficus-indica lectin (OfiL) on the survival and nutritional parameters of Sitophilus zeamais (maize weevil) adults were evaluated. OfiL was incorporated into the artificial diets at concentrations of 15,60, and $95 \mathrm{mg} / \mathrm{g}$ (mg of lectin per $\mathrm{g}$ of wheat flour). Mortality was evaluated after 7 and 15 days, and the amount of food ingested and the weight of the insects were determined on the 7th day. In addition, the in vitro effects of OfiL on the gut enzymes of the insect were investigated. The ingestion of OfiL did not show any significant difference in the mortality rates compared to control. The relative consumption rate was also similar to that of the control, and no deterrent effect was detected. However, the values of the relative biomass variation and the efficiency of ingested food conversion were negative in the treatments at 60 and $95 \mathrm{mg} / \mathrm{g}$, showing that lectin ingestion resulted in weight loss. OfiL exhibited a stimulatory effect on the protease activity from $S$. zeamais gut extract, which may cause uncontrolled hydrolysis of proteins in the digestive tract. This lectin did not promote significant alteration in the amylase activity. In conclusion, OfiL was able to exert anti-nutritional effects without causing a deterrent effect.
\end{abstract}

Thiago Henrique Napoleão

thiagohn86@yahoo.com.br

1 Departamento de Bioquímica, Centro de Biociências, Universidade Federal de Pernambuco, Recife, Pernambuco, Brazil

2 Departamento de Bioquímica e Farmacologia, Universidade Federal do Piauí, Teresina, Piauí, Brazil

3 Departamento de Morfologia e Fisiologia Animal, Universidade Federal Rural de Pernambuco, Recife, Pernambuco, Brazil
Keywords Indian-fig - Lectin - Insecticidal activity · Greater rice weevil $\cdot$ Agricultural pest

\section{Introduction}

The weevils belonging to Sitophilus genus (Family: Curculionidae) are cosmopolitan insects found in the tropical regions and are able to infest grains of major importance such as rice, wheat, and maize [1]. The grains are the nutrient source for these insects and serve as the shelter for the immature forms, which develop inside them [2].

Sitophilus zeamais is one of the main pests of maize; however, it also attacks other crops such as rice, wheat, and sorghum, in addition to fruits and processed foods [3, 4]. The potential to promote cross-infestation and the high capacity for penetration and destruction of the grains account for the high economic impact of this insect $[1,5]$. In addition, a remarkable plasticity at the individual and population levels renders the control of this pest very difficult [6]. The presence of $S$. zeamais also facilitates the dissemination of pathogens and contamination by fungal toxins at storage [7, 8].

The control of stored grain pests has been mainly performed by cleaning of the grains, aeration, temperature and moisture regulation, and application of insecticides [1]. The use of methyl bromide and phosphine is commonly used as the main strategy for the control of storage pests. However, these compounds were reported to be highly toxic to the environment and humans, which has led to the search for alternative non-chemical methods of control (e.g., heat treatments and entomopathogenic fungi) and for more environmentally friendly insecticides (e.g., plant essential oils and entomotoxic proteins) [9-12]. In 
addition, there are reports on the insecticidal-resistant populations of $S$. zeamais exposed to selective pressures under laboratory conditions or found directly in the field [13-16].

Lectins are carbohydrate-binding proteins broadly found in plants. One of the roles of these proteins is the defense against pathogens, predators, and herbivores $[17,18]$. They have been described as insecticidal agents against species of the orders Coleoptera, Diptera, Hemiptera, Homoptera, Hymenoptera, Isoptera, Lepidoptera, and Neuroptera, acting on both immature and adult forms [19]. Many of the insecticidal lectins have a chitin-binding ability, which allows them to interact with important structures of the insect body that are composed of this polysaccharide [20]. In addition, lectins may interfere with insect physiology and behavior. A lectin from Myracrodruon urundeuva leaf was reported to be a strong feeding deterrent to $S$. zeamais adults and was able to impair the digestive process of this insect by enzyme modulatory effects [10].

The cladodes of Opuntia ficus-indica (L.) Mill. (Cactaceae) contain a chitin-binding lectin (deemed OfiL) that has been previously isolated and characterized [21]. OfiL showed antifungal activity against phytopathogens and insecticidal activity against Nasutitermes corniger termite $[21,22]$. In this work, the effects of OfiL on the survival and nutritional parameters of $S$. zeamais adults were evaluated.

\section{Materials and methods}

\section{Plant material and insects}

Cladodes of $O$. ficus-indica were collected in Limoeiro, Pernambuco, Brazil, with authorization (36301) of the Instituto Chico Mendes de Conservação da Biodiversidade (ICMBio). The cladodes were dried for 7 days $\left(27 \pm 2{ }^{\circ} \mathrm{C}\right.$; relative humidity of $70 \pm 5 \%$ ), powdered, and stored at $28{ }^{\circ} \mathrm{C}$. The insects are reared in the Laboratório de Bioquímica de Proteínas, Departamento de Bioquímica, Universidade Federal de Pernambuco since 2012. The colonies were maintained at $28 \pm 2{ }^{\circ} \mathrm{C}$ in glass containers (capacity, $1 \mathrm{~L}$ ) sealed with unwoven fabric to allow aeration. The diet consisted of maize grains (100 g per container), which was selected based on the integrity, sanitary conditions, size, and absence of contamination with other insects.

\section{Isolation of OfiL}

OfiL was isolated according to Santana et al. [21], initiating with the extraction of proteins from the cladodes using $0.15 \mathrm{M} \mathrm{NaCl}$, followed by chromatography using a chitin column. Lectin concentration was determined according to Lowry et al. [23] using bovine serum albumin $(31.25-500 \mu \mathrm{g} / \mathrm{mL})$ as the standard. Carbohydrate-binding ability was monitored through the hemagglutination assay, which was carried out in microtiter plates according to Procópio et al. [24] using rabbit erythrocytes treated with glutaraldehyde [25]. The collection of erythrocytes was approved by the Ethics Committee on Animal Experimentation of the Universidade Federal de Pernambuco (23076.033782/2015-70).

\section{Insecticidal assay}

Insecticidal activity was evaluated using a modified version of the method of Xie et al. [26], as described by Napoleão et al. [10]. First, wheat flour suspensions were prepared, each one consisting of $2.0 \mathrm{~g}$ of autoclaved wheat flour (Bunge Alimentos S.A., Benevides, Brazil), homogenized in $5 \mathrm{~mL}$ of sterile distilled water (control) or a solution containing OfiL diluted in the sterile water. In each assay, five aliquots $(200 \mu \mathrm{L})$ were placed on a petri dish $(90 \times 100 \mathrm{~mm})$ to form flour disks after overnight incubation at $56{ }^{\circ} \mathrm{C}$. Next, each dish containing the disks was weighed. Twelve $S$. zeamais adults with known weight were then transferred to each dish. The assays were maintained at $25 \pm 2{ }^{\circ} \mathrm{C}$ in the dark for 7 days. After this period, the mortality rate and the weights of dishes (containing the broken flour disks) and insects were recorded again. Mortality was also evaluated on the 15 th day. The assays were performed in quadruplicate, and the tested lectin concentrations ( $\mathrm{mg}$ of lectin/g of wheat flour) were 15,60 , and $95 \mathrm{mg} / \mathrm{g}$.

\section{Feeding deterrence evaluation}

The feeding deterrence index (FDI) was calculated as follows: FDI $(\%)=100 \times(X-Y) /(X)$, where $X$ is the mass of the food ingested by the insects in the control assay and $Y$ is the mass of the food ingested by the insects in the lectin assay [27]. According to the FDI value, the lectin was classified as: non-deterrent (FDI $<20 \%$ ), weak deterrent $(50 \%>$ FDI $\geq 20 \%)$, moderate deterrent $(70 \%>$ FDI $\geq 50 \%)$, or strong deterrent $(\mathrm{FDI} \geq 70 \%)$.

\section{Nutritional parameters}

The data recorded at the end of the insecticidal assay were used to calculate the following nutritional parameters [26]: (1) the relative consumption rate $=A /(B \times$ days $)$, where $A$ is the mass of the ingested food in $\mathrm{mg}$ and $B$ corresponds to the initial insect biomass in $\mathrm{mg}$; (2) the relative biomass variation $=C /(B \times$ days $)$, where $C$ corresponds to the insect biomass variation in $\mathrm{mg}$, after 7 days from the 
beginning of the experiment; and (3) the efficiency of conversion of ingested food $=C /(A \times 100)$.

\section{Gut preparations from $S$. zeamais}

Groups of fifty $S$. zeamais adults were collected and immobilized by exposure to $-20^{\circ} \mathrm{C}$ for $20 \mathrm{~min}$. The guts were dissected by hand and homogenized in $1 \mathrm{~mL}$ of Tris buffer (0.1 M Tris-HCl, pH 8.0, containing $0.02 \mathrm{M} \mathrm{CaCl}_{2}$ and $0.15 \mathrm{M} \mathrm{NaCl})$ or acetate buffer $(0.1 \mathrm{M}$ sodium acetate, pH 5.5, containing $0.02 \mathrm{M} \mathrm{CaCl}_{2}$ and $0.15 \mathrm{M} \mathrm{NaCl}$ ) using a 3-mL tissue grinder. The homogenates were centrifuged at $9000 \times g$ at $4{ }^{\circ} \mathrm{C}$ for $15 \mathrm{~min}$. The supernatants (gut extracts) were collected, and the protein concentration [23] and enzyme activity (as described below) were evaluated.

\section{Enzyme assays}

Protease activity was determined according to Azeez et al. [28]. Briefly, the gut extract in Tris buffer $(50 \mu \mathrm{L} ; 350 \mu \mathrm{g}$ of protein) was previously incubated $\left(15 \mathrm{~min}, 28^{\circ} \mathrm{C}\right)$ with $50 \mu \mathrm{L}$ of OfiL $(1.5-20 \mu \mathrm{g})$ or distilled water $(100 \%$ activity control) and then mixed with $300 \mu \mathrm{L}$ of $0.1 \mathrm{M}$ sodium phosphate, $\mathrm{pH} 7.5$, containing $50 \mu \mathrm{L}$ of $0.6 \%(\mathrm{w} / \mathrm{v})$ azocasein. The mixture was supplemented with $100 \mu \mathrm{L}$ of $0.1 \%(\mathrm{v} / \mathrm{v})$ Triton $\mathrm{X}-100$ and incubated at $37{ }^{\circ} \mathrm{C}$ for $3 \mathrm{~h}$. The reaction was stopped by adding $200 \mu \mathrm{L}$ of $10 \%(\mathrm{v} / \mathrm{v})$ trichloroacetic acid (TCA), and the assay was incubated at $4{ }^{\circ} \mathrm{C}$ for $30 \mathrm{~min}$. Each assay was accompanied by a blank (identical to the test except that TCA was added before the addition of azocasein). Next, it was centrifuged at $9000 \times g$ for $10 \mathrm{~min}$, and the absorbance of the supernatant was determined at $366 \mathrm{~nm}$ using a spectrophotometer. One unit of protease activity was defined as the amount of enzyme that yielded an increase of 0.01 in the absorbance. A control assay containing OfiL without the gut extract was also performed. The assays were performed in triplicate.

$\alpha$-Amylase activity assay was carried out based on the method described by Bernfeld [29]. Briefly, the gut extract in acetate buffer $(100 \mu \mathrm{L} ; 600 \mu \mathrm{g}$ of protein) was previously incubated $\left(15 \mathrm{~min}, 28^{\circ} \mathrm{C}\right)$ with $100 \mu \mathrm{L}$ of OfiL $(1.5-100 \mu \mathrm{g})$ or distilled water $(100 \%$ activity control). Next, the samples were incubated at $50{ }^{\circ} \mathrm{C}$ for $10 \mathrm{~min}$ with $400 \mu \mathrm{L}$ of $1 \%(\mathrm{w} / \mathrm{v})$ soluble starch solution in acetate buffer. The reaction was stopped by adding $500 \mu \mathrm{L}$ of 3,5dinitrosalicylic acid (DNS) reagent. Then, the assays were heated at $100{ }^{\circ} \mathrm{C}$ in boiling water for $6 \mathrm{~min}$ and immediately cooled on ice for $15 \mathrm{~min}$. The absorbance was measured at $540 \mathrm{~nm}$ using a spectrophotometer, and the amount of reducing sugars was calculated using a standard curve of the reaction between glucose and DNS reagent. One unit of the $\alpha$-amylase activity was defined as the amount of enzyme required to generate $1 \mu \mathrm{mol}$ of glucose per minute. Reaction blanks were performed without starch. The assays were performed in triplicate.

\section{Statistical analysis}

The data were expressed as the mean of replicates \pm standard deviations (SD). Significant differences between the treatment groups were analyzed by one-way analysis of variance (ANOVA), followed by Tukey's test, with a significance level at $p<0.05$. The analyses were performed using the Action 2.4.163.322 software (Estatcamp, São Carlos, Brazil).

\section{Results}

The ingestion of OfiL did not result in significant difference $(p>0.05)$ in the mortality rates in comparison with the control group after 7 and 15 days of the assay (Table 1). The relative consumption rate was also similar to that of the control $(p>0.05)$ in all the treatments, showing that the presence of OfiL did not affect the intake of diet (Fig. 1A). Indeed, the calculation of FDI revealed no deterrent effect.

Although OfiL did not cause insect death, the relative biomass variation was negative for the treatments at 60 and $95 \mathrm{mg} / \mathrm{g}$ (Fig. 1B), showing that lectin ingestion resulted in the decrease in body weight. The data on the efficiency of the conversion of the ingested food are in agreement with the loss of biomass of the insects, because the feed conversion values were also negative for the treatments at 60 and $95 \mathrm{mg} / \mathrm{g}$ (Fig. 1C).

OfiL exhibited a stimulatory effect on the protease activity from S. zeamais gut extract (Fig. 2). Concerning the $\alpha$-amylase activity, OfiL was not able to promote significant reduction in starch hydrolysis (Fig. 2B), when $S$. zeamais gut extract was previously incubated with it.

Table 1 Mortality of Sitophilus zeamais adults maintained for 7 and 15 days on artificial diets containing the lectin OfiL

\begin{tabular}{lll}
\hline Treatment & \multicolumn{2}{l}{ Mortality rate $(\%)$} \\
\cline { 2 - 3 } & 7 days & 15 days \\
\hline Control & $2.5 \pm 2.8 \mathrm{a}$ & $16.2 \pm 4.8 \mathrm{a}$ \\
OfiL $(\mathrm{mg} / \mathrm{g})$ & \\
15 & $2.5 \pm 2.8 \mathrm{a}$ & $23.2 \pm 5.5 \mathrm{a}$ \\
60 & $7.5 \pm 2.8 \mathrm{a}$ & $21.0 \pm 5.3 \mathrm{a}$ \\
95 & $1.2 \pm 2.5 \mathrm{a}$ & $20.0 \pm 7.1 \mathrm{a}$ \\
\hline
\end{tabular}

Significant differences were not observed between the treatments $(p>0.05)$ 

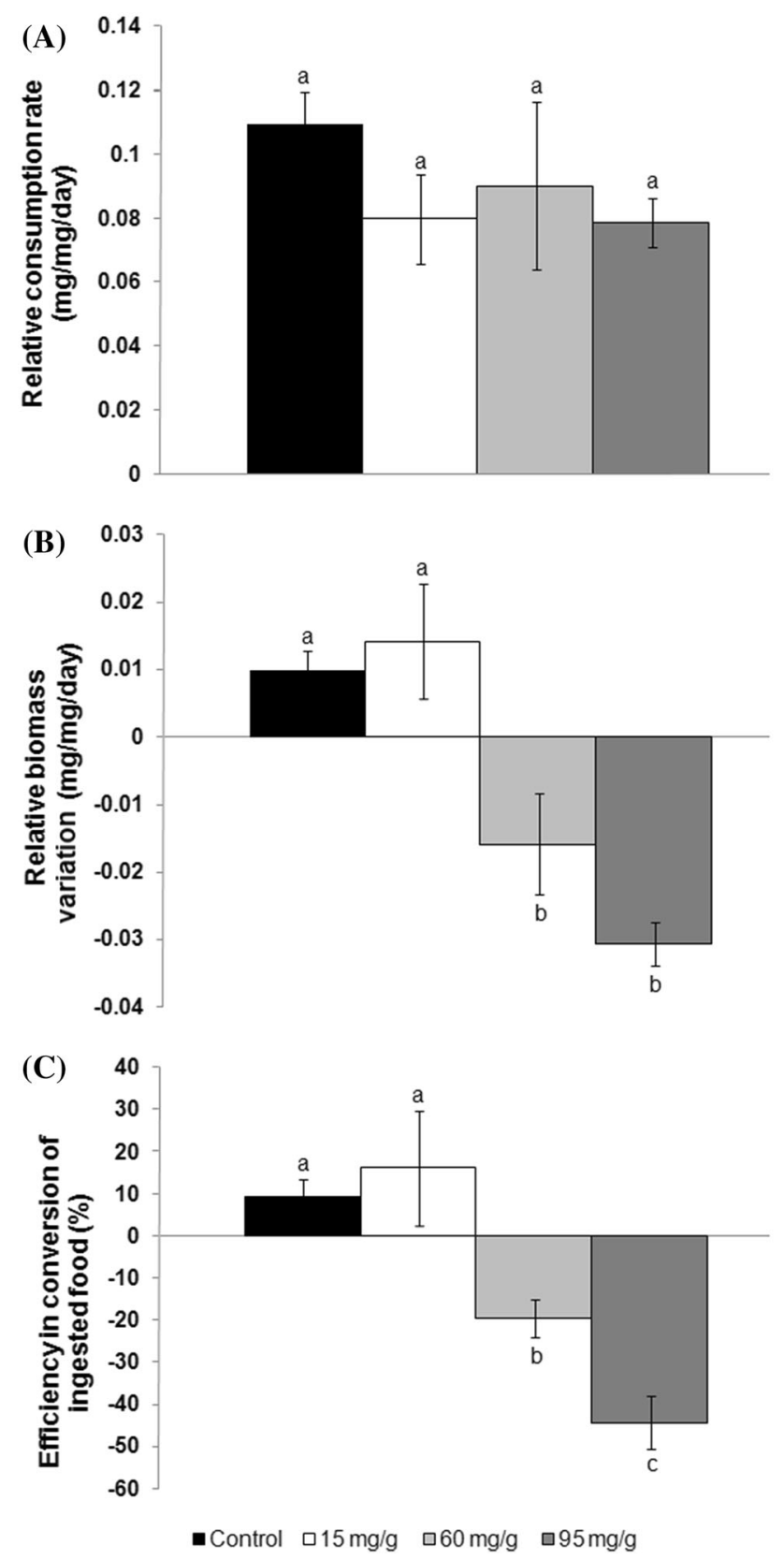

Fig. 1 Nutritional parameters of Sitophilus zeamais adults reared on artificial diets consisting of wheat flour disks without (control) or with Opuntia ficus-indica lectin (OfiL, 15-95 mg of lectin per $\mathrm{g}$ of wheat flour). (A) The relative consumption rate indicates the mean estimative of the amount of food consumed in mg per mg of insect body weight per day. (B) The relative biomass variation indicates the mean estimative of the amount of biomass in mg gained or lost every day per $\mathrm{mg}$ of initial body weight. (C) The efficiency in conversion of ingested food (\%) indicates the amount of ingested food incorporated by insects as biomass after 7 days from the beginning of the experiment. Each bar corresponds to the mean \pm SD of four replicates. Different letters indicate significant $(p<0.05)$ differences between treatments
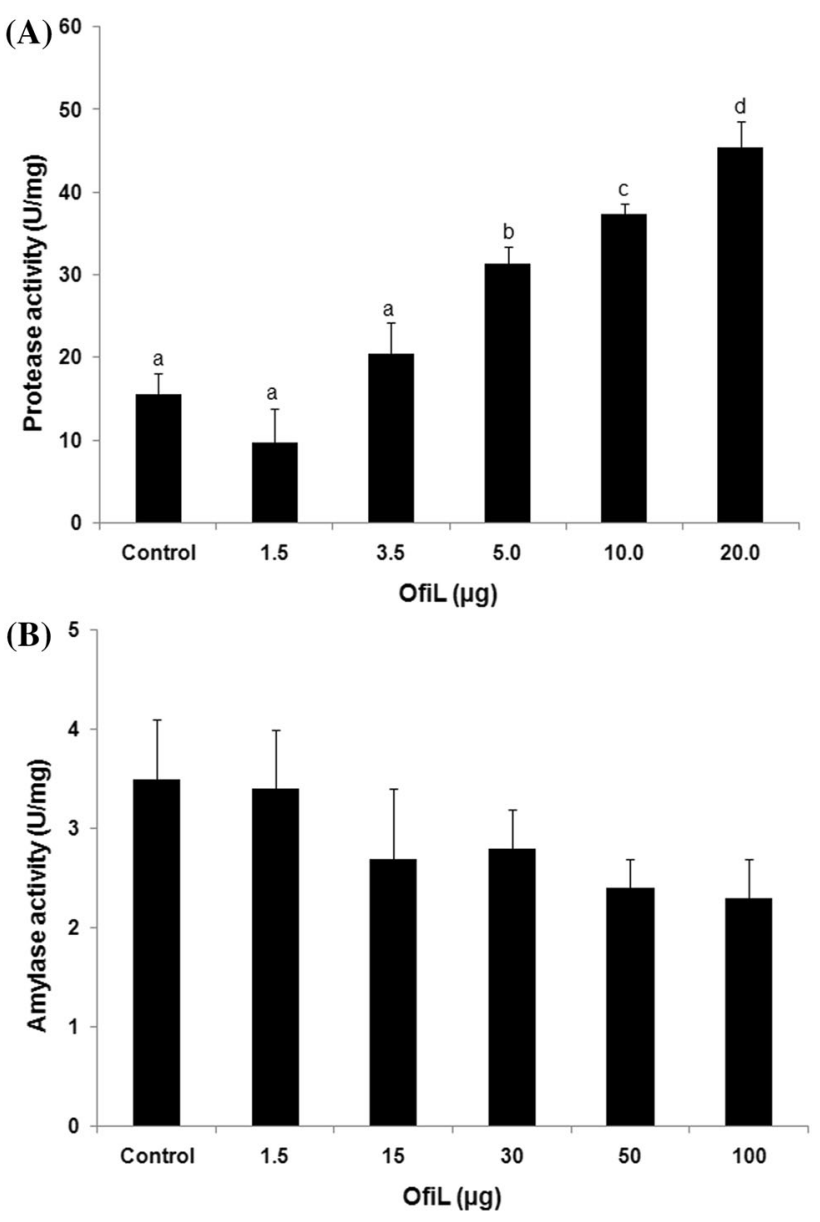

Fig. 2 Protease (A) and $\alpha$-amylase (B) activities from Sitophilus zeamais gut extracts incubated with or without Opuntia ficus-indica lectin (OfiL). Each bar corresponds to the mean \pm SD of three replicates. Different letters indicate significant $(p<0.05)$ differences between the assays

\section{Discussion}

The entomotoxic effects of lectins have been reported, and the potential of these proteins in crop protection has been indicated in several studies $[12,19,20]$. The ingestion of plant lectins might exert deleterious effects on insects at all stages, interfering with survival, feeding, morphology, and development. In this study, we investigated the effect of an artificial diet composed of wheat flour and the lectin OfiL on the survival and nutritional parameters of $S$. zeamais adults. For this, the OfiL isolation procedure was repeated about 30 times, yielding a lectin amount sufficient for the insecticidal assays at concentrations of 15,60 , and $95 \mathrm{mg} /$ g.

Similar to OfiL, the lectin from M. urundeuva leaf (MuLL) did not promote mortality in $S$. zeamais adults after 7 days of treatment [10]. However, the authors partly attributed this result to the feeding-deterrent action of MuLL, which was not ingested by the insects and thus not 
able to exert acute toxic effects. In the present study, the insects did not avoid the diet containing OfiL, and thus, the absence of mortality might not be explained as in case of MuLL. It is plausible that damage in the gut of $S$. zeamais adults was not caused by OfiL, or, if it occurred, was not sufficient to promote the death of the insects in the periods evaluated.

It is possible that OfiL, when present in the digestive tract of $S$. zeamais adults, interfered with the digestion and absorption process, and thus, the food was not converted into biomass. The decrease in weight was a consequence of this, because the energy spent by the insects for their physiological processes was greater than the energy that could be harnessed from feeding.

S. zeamais adults provided with diet containing MuLL also showed negative values of biomass variation and food conversion. However, although the final effect was similar, the mechanism involved was probably different. The insects treated with MuLL lost biomass because of the starvation process as a consequence of the deterrent effect. In the case of OfiL, the diet was ingested; however, it was not metabolically useful to the insects. Similar results obtained with OfiL have been reported in studies using lectins and other insects. Reduction in the weight and efficiency of food conversion into body mass were detected in Anagasta kuehniella larvae, when these insects were maintained with an artificial diet containing $M$. oleifera seed lectins [30, 31]. The ingestion of Dioclea violacea lectin also decreased A. kuehniella larval mass without affecting its survival [32].

The results instigated us to evaluate whether OfiL would be able to interfere with the activity of digestive enzymes present in the gut of $S$. zeamais adults. At the first glance, this stimulatory effect on proteases might be considered positive for the insects because such protease stimulus might facilitate digestion; however, an imbalance in the proteolysis is usually damaging because it might lead to the disruption of the intestinal tract organization. For example, it has been demonstrated that the water-soluble lectin from M. oleifera seeds, which shows larvicidal activity against Aedes aegypti, was able to stimulate the protease activity at the same time that induces strong damage to the epithelial organization of larvae gut [33, 34]. These effects could impair both digestion and nutrient absorption.

The absence of significant effect on amylase activity indicates that a direct inhibitory effect of this lectin on amylases might not be a major explanation for the reduction in the efficiency of food conversion. However, the possibility of uncontrolled digestion of enzyme molecules by proteases stimulated by OfiL, resulting in an indirect impairment in the digestion of the starch present in wheat flour, should be considered.
Chitin-binding lectins usually bind the peritrophic membrane, which is a structure composed of chitin and glycoproteins that protect the gut epithelium from insects against abrasion by plant fragments and infection by pathogens and also play a compartmentalization role in the digestive process [35]. The disruption of the peritrophic membrane may result in the deregulation of the action of enzymes and allow the access of the lectins to the gut microvillar brush border and epithelial cells. Once a lectin reaches these structures, it might interfere with several physiological processes, including the absorption of nutrients [19, 36, 37]. Powell et al. [38] showed that Galanthus nivalis agglutinin caused the disruption of the microvilli brush border region of Nilaparvata lugens.

The D. violacea lectin, which was not able to kill $A$. kuehniella larvae, but affected their nutrition, was able to bind to the peritrophic membrane [32]. The chitin-binding lectins from the bark, heartwood, and leaf of M. urundeuva were able to induce apoptosis in the digestive and enteroendocrine cells of $N$. corniger gut and consequently block the absorption of nutrients and deregulate the coordination of enzyme release into the gut lumen [39]. Alterations in the expression profile of genes in the gut of insects fed on artificial diets containing chitin-binding lectin from wheat germ have also been reported; some of these genes are linked to the expression of digestive enzymes and energy metabolism [40]. In summary, although OfiL did not induce acute lethality in S. zeamais adults, it caused an intoxication effect that led to the malnutrition of these insects. Some of these mechanisms already reported for other lectins might be involved, which warrants future studies on this aspect.

The nutritional impairment in the insects might lead to disturbances other than mortality that might affect their efficiency as pests. An inadequate nutrition status results in a deficient metabolic functioning, which can affect the fecundity and longevity [20, 41, 42]. A methanolic extract from Syzygium aromaticum flower buds had no effect on the mortality of $S$. zeamais but promoted a reduction of $37 \%$ in the $\mathrm{F}_{1}$ progeny, and $\mathrm{n}$-hexane extract from this same plant material showed toxicity through a possible stomach action and reduced the $\mathrm{F}_{1}$ progeny in 99\% [43]. This is important to reduce the impact of a pest such as $S$. zeamais, which is known for a destructive potential linked to a high reproductive fitness. In addition, compounds able to affect the insect physiology without promoting their death are important; for example, to be used as synergists or to obtain long-term effects without an increase in the selective pressure that could result in resistance establishment.

In conclusion, OfiL is a type of lectin reported to be active against $S$. zeamais adults. This lectin is able to exert anti-nutritional effects without causing a deterrent effect. 
The results warrant new investigations aiming to explore the effect of OfiL on the long-term assays as well as synergists of other insecticides.

Acknowledgments The authors express their gratitude to the Conselho Nacional de Desenvolvimento Científico e Tecnológico $(\mathrm{CNPq}$; 446902/2014-4; 408789/2016-6) for research grants and fellowship (PMGP). They are also grateful to the Coordenação de Aperfeiçoamento de Pessoal de Nivel Superior (CAPES; AUXPE 1454/2013) and the Fundação de Amparo à Ciência e Tecnologia do Estado de Pernambuco (FACEPE; APQ-0137-2.08/12; APQ-0108-2.08/14; APQ-0661-2.08/15) for financial support.

\section{Compliance with ethical standards}

Conflict of interest The authors declare that they have no conflict of interest.

\section{References}

1. Napoleão TH, Agra-Neto AC, Belmonte BR, Pontual EV, Paiva PMG (2015) Biology, ecology and strategies for control of stored-grain beetles: a review. In: Stack C (ed) Beetles: biodiversity, ecology and role in the environment. Nova Science Publishers Inc., New York, pp 105-122

2. Gallo D, Nakano O, Silveira Neto S, Carvalho RPL, Batista GC, Berti Filho E, Parra JRP, Zucchi RA, Alves SB, Vendramim JD, Marchini IC, Lopes JRS, Omoto G (2002) Entomologia Agrícola. FEALQ, Piracicaba

3. Botton M, Lorini I, Afonso APS (2005) Ocorrência de Sitophilus zeamais Mots. (Coleoptera: Curculionidae) danificando a cultura da videira no Rio Grande do Sul. Neotrop Entomol 34:355-356

4. Fazolin M, Costa CR, Damaceno JEO, Albuquerque ES, Cavalcante ASS, Estrela JLV (2010) Fumigação de milho para o controle do gorgulho utilizando caule de Tanaecium nocturnum (Bignoniaceae). Pesq Agropecu Bras 45:1-6

5. Suleiman RA, Rosentrater KA (2015) Current maize production, postharvest losses and the risk of mycotoxins contamination in Tanzania. In: Agricultural and biosystems engineering conference proceedings and presentations. https://doi.org/10.13031/aim. 20152189434

6. Morales JA, Cardoso DG, Della Lucia TMC, Guedes RNC (2013) Weevil $x$ insecticide: does 'personality' matter? PLoS ONE 8:e67283

7. Beti JA, Philips TW, Smalley EB (1995) Effects of maize weevils (Coleoptera: Curculionidae) on production of aflatoxin B1 by Aspergillus flavus in stored corn. J Econ Entomol 88:1776-1782

8. Gnonlonfin GJB, Hell K, Adjovi Y, Fandohan P, Koudande DO, Mensah GA, Sanni A, Brimer L (2013) A review on aflatoxin contamination and its implications in the developing world: a sub-Saharan African perspective. Crit Rev Food Sci Nutr 53:349-365

9. Barra P, Rosso L, Nesci A, Etcheverry M (2013) Isolation and identification of entomopathogenic fungi and their evaluation against Tribolium confusum, Sitophilus zeamais, and Rhyzopertha dominica in stored maize. J Pest Sci 86:217-226

10. Napoleão TH, Belmonte BR, Pontual EV, Albuquerque LP, Sá RA, Paiva LM, Coelho LCBB, Paiva PMG (2013) Deleterious effects of Myracrodruon urundeuva leaf extract and lectin on the maize weevil, Sitophilus zeamais (Coleoptera, Curculionidae). J Stored Prod Res 54:26-33

11. Lü J, Zhang H (2016) The effect of acclimation to sublethal temperature on subsequent susceptibility of Sitophilus zeamais
Mostchulsky (Coleoptera: Curculionidae) to high temperatures. PLoS ONE 11:e0159400

12. Camaroti JRSL, Oliveira APS, Paiva PMG, Pontual EV, Napoleão TH (2017) Phytoinsecticides for controlling pests and mosquito vectors of diseases. In: Green V (ed) Biocontrol agents: types, applications and research insights. Nova Science Publishers Inc., New York, pp 147-188

13. Araújo RA, Williamson MS, Bass C, Field LM, Duce IR (2011) Pyrethroid resistance in Sitophilus zeamais is associated with a mutation (T929I) in the voltage gated sodium channel. Insect Mol Biol 20:437-445

14. Haddi K, Mendonça LP, Santos MF, Guedes RN, Oliveira EE (2015) Metabolic and behavioral mechanisms of indoxacarb resistance in Sitophilus zeamais (Coleoptera: Curculionidae). J Econ Entomol 108:362-369

15. Freitas RCP, Faroni LRD, Haddi K, Jumbo LOV, Oliveira EE (2016) Allyl isothiocyanate actions on populations of Sitophilus zeamais resistant to phosphine: toxicity, emergence inhibition and repellency. J Stored Prod Res 69:257-264

16. Cordeiro EMG, Corrêa AS, Denadai CAR, Tomé HVV, Guedes RNC (2017) Insecticide resistance and size assortative mating in females of the maize weevil (Sitophilus zeamais). Pest Manag Sci 73:823-829

17. Lannoo N, Van Damme EJM (2014) Lectin domains at the frontiers of plant defense. Front Plant Sci 5:397

18. Procópio TF, Moura MC, Albuquerque LP, Gomes FS, Santos NDL, Coelho LCBB, Pontual EV, Napoleão TH (2017) Antibacterial lectins: action mechanisms, defensive roles and biotechnological potential. In: Collins E (ed) Antibacterials: synthesis, properties and biological activities. Nova Science Publishers Inc., New York, pp 69-89

19. Paiva PMG, Pontual EV, Napoleão TH, Coelho LCBB (2013) Lectins and trypsin inhibitors from plants. Biochemical characteristics and adverse effects on insect larvae. Nova Science Publishers Inc., New York

20. Macedo MLR, Oliveira CFR, Oliveira CT (2015) Insecticidal activity of plant lectins and potential application in crop protection. Molecules 20:2014-2033

21. Santana GMS, Albuquerque LP, Simões DA, Gusmão NB, Coelho LCBB, Paiva PMG (2009) Isolation of lectin from Opuntia fícus indica cladodes. Acta Hortic 811:281-286

22. Paiva PMG, Santana GMS, Souza IFAC, Albuquerque LP, AgraNeto AC, Albuquerque AC, Luz LA, Napoleão TH, Coelho LCBB (2011) Effect of lectins from Opuntia ficus-indica cladodes and Moringa oleifera seeds on survival of Nasutitermes corniger. Int Biodeterior Biodegrad 65:982-989

23. Lowry OH, Rosebrough NJ, Farr AL, Randall RJ (1951) Protein measurement with the Folin phenol reagent. J Biol Chem 193:265-275

24. Procópio TF, Patriota LLS, Moura MC, Silva PM, Oliveira APS, Carvalho LVN, Lima TA, Coelho LCBB, Soares T, Silva TD, Pitta MGR, Rêgo MJBM, Figueiredo RCBQ, Paiva PMG, Napoleão TH (2017) CasuL: a new lectin isolated from Calliandra surinamensis leaf pinnulae with cytotoxicity to cancer cells, antimicrobial activity and antibiofilm effect. Int J Biol Macromol 98:419-429

25. Bing DH, Weyand JGM, Stavistsky AB (1967) Hemagglutination with aldehyde-fixed erythrocytes for assay of antigens and antibodies. Proc Soc Exp Biol Med 124:1166-1170

26. Xie YS, Bodnaryk RP, Fields PG (1996) A rapid and simple flour-disk bioassay for testing substances active against storedproduct insects. Can Entomol 28:865-875

27. Isman MB, Koul O, Luczynski A, Kaminski J (1990) Insecticidal and antifeedant bioactivities of neem oils and their relationship to azadirachtin content. J Agric Food Chem 38:1406-1411 
28. Azeez A, Sane AP, Bhatnagar D, Nath P (2007) Enhanced expression of serine proteases during floral senescence in Gladiolus. Phytochemistry 68:1352-1357

29. Bernfeld P (1955) Amylases, $\alpha$ and $\beta$. Methods Enzymol 1:149-158

30. Oliveira CFR, Luz LA, Paiva PMG, Coelho LCBB, Marangoni S, Macedo MLR (2011) Evaluation of seed coagulant Moringa oleifera lectin $(\mathrm{cMoL})$ as a bioinsecticidal tool with potential for the control of insects. Process Biochem 46:498-504

31. Oliveira CFR, Moura MC, Napoleão TH, Paiva PMG, Coelho LCBB, Macedo MLR (2017) A chitin-binding lectin from Moringa oleifera seeds (WSMoL) impairs digestive physiology of the mediterranean flour larvae, Anagasta kuehniella. Pestic Biochem Physiol 142:67-76

32. Oliveira CT, Kunz D, Silva CP, Macedo MLR (2015) Entomotoxic properties of Dioclea violacea lectin and its effects on digestive enzymes of Anagasta kuehniella (Lepidoptera). J Insect Physiol 81:81-89

33. Coelho JS, Santos NDL, Napoleão TH, Gomes FS, Ferreira RS, Zingali RB, Coelho LCBB, Navarro DMAF, Paiva PMG (2009) Effect of Moringa oleifera lectin on development and mortality of Aedes aegypti larvae. Chemosphere 77:934-938

34. Agra-Neto AC, Napoleão TH, Pontual EV, Santos NDL, Luz LA, Oliveira CMF, Melo-Santos MAV, Coelho LCBB, Navarro DMAF, Paiva PMG (2014) Effect of Moringa oleifera lectins on survival and enzyme activities of Aedes aegypti larvae susceptible and resistant to organophosphate. Parasitol Res 113:175-184

35. Tellam RL, Wijffels G, Willadsen P (1999) Peritrophic matrix proteins. Insect Biochem Mol Biol 29:87-101

36. Vandenborre G, Smagghe G, Van Damme EJM (2011) Plant lectins as defense proteins against phytophagous insects. Phytochemistry $72: 1538-1550$
37. Lima TA, Dornelles LP, Oliveira APS, Guedes CCS, Souza SO, Sá RA, Zingali RB, Napoleão TH, Paiva PMG (2018) Binding targets of termiticidal lectins from the bark and leaf of Myracrodruon urundeuva in the gut of Nasutitermes corniger workers. Pest Manag Sci. https://doi.org/10.1002/ps.4847

38. Powell KS, Spence J, Bharathi M, Gatehouse JA, Gatehouse AMR (1998) Immunohistochemical and developmental studies to elucidate the mechanism of action of the snowdrop lectin on the rice brown planthopper, Nilaparvata lugens (Stal). J Insect Physiol 44:529-539

39. Lima TA, Fernandes KM, Oliveira APS, Dornelles LP, Martins GF, Napoleão TH, Paiva PMG (2017) Termiticidal lectins from Myracrodruon urundeuva (Anacardiaceae) cause midgut damages when ingested by Nasutitermes corniger (Isoptera; Termitidae) workers. Pest Manag Sci 73:991-998

40. Li HM, Sun L, Mittapalli O, Muir WM, Xie J, Wu J, Schemerhorn BJ, Sun W, Pittendrigh BR, Murdock LL (2009) Transcriptional signatures in response to wheat germ agglutinin and starvation in Drosophila melanogaster larval midgut. Insect Mol Biol 18:21-31

41. Pompermayer P, Falco MC, Parra JRP, Silva-Filho MC (2003) Coupling diet quality and Bowman-Birk and Kunitz-type soybean proteinase inhibitor effectiveness to Diatraea saccharalis development and mortality. Entomol Exp Appl 109:217-224

42. May CM, Doroszuk A, Zwaan BJ (2015) The effect of developmental nutrition on life span and fecundity depends on the adult reproductive environment in Drosophila melanogaster. Ecol Evol 5:1156-1168

43. Ho SH, Cheng LPL, Sim KY, Tan HTW (1994) Potential of cloves (Syzygium aromaticum (L.) Merr. and Perry) as a grain protectant against Tribolium castaneum (Herbst) and Sitophilus zeamais Motsch. Postharvest Biol Technol 4:179-183 